ZORAN PAPIĆ, Ph.D. ${ }^{1}$

(Corresponding author)

E-mail: njele@uns.ac.rs

GORAN ZOVAK, Ph.D. ${ }^{2}$

E-mail: goran.zovak@fpz.hr

VUK BOGDANOVIĆ, Ph.D. ${ }^{1}$

E-mail: vuk@uns.ac.rs

NENAD SAULIĆ, M.Sc.1

E-mail: nenadsaulic@gmail.com

${ }^{1}$ University of Novi Sad, Faculty of Technical Sciences

Department of Traffic Engineering

Trg Dositeja Obradovića 6, 21000 Novi Sad, Serbia

2 University of Zagreb,

Faculty of Transport and Traffic Sciences

Vukelićeva 4, 10000 Zagreb, Croatia
Safety and Security in Traffic

Preliminary Communication

Submitted: July 16, 2015

Accepted: Apr. 12, 2016

\title{
EMPIRICAL APPROACH FOR DETERMINING LANE CHANGE DISTANCE AT OBSTACLE AVOIDANCE MANOEUVRE
}

\begin{abstract}
The lane change of vehicles for avoiding hitting a sudden obstacle represents a significant and unique problem for traffic accident experts. Most mathematic models for determining the lane change distance are based on theoretical research studies and a lot of simplifications and approximations. In order to analyse the influence of different drivers and vehicles on a manoeuvre, an experimental research study of lane change was carried out at the test track which enables repeatability in the same conditions. The drivers were instructed to drive through the test track at a maximum speed without displacing the traffic cones. Based on the statistical analyses of the successful lane change manoeuvres an empirical model for the calculation of lane change distance for obstacle avoidance was formed. This model can be applied in the procedure of traffic accident reconstructions as well as within the development of the concept of modern intelligent vehicles.
\end{abstract}

\section{KEY WORDS}

lane change; obstacle avoidance; lateral acceleration; distance; model;

\section{INTRODUCTION}

Vehicle lateral movement for lane change or overtaking, as well as obstacle avoidance, represent important and unique problems for traffic accident reconstructionists. During their research of real-life traffic accidents, Malaterre et al. [1] determined that in the situations of a sudden encounter with an obstacle, drivers mostly tried to avoid crash by braking. If lateral manoeuvre was attempted, the drivers moved the vehicle mostly in the direction in which the obstacle was moving. Limpert and Gamero [2] determined, within a multi-disciplinary analysis of traffic accidents, on a sample of 100 accidents, that $56 \%$ of the drivers tried to avoid crash by braking, while $7.5 \%$ performed steering. Both braking and steering were performed by $15 \%$ of the drivers. This research determined that as the speed of the vehicle participating in the accident increased, the number of drivers that tried to avoid accident by performing lateral manoeuvre increased as well. Critical speed, at which the crash with an obstacle cannot be avoided by braking, but only by a possible lateral manoeuvre, was defined based on the research. Research by Hatterick and Bathurst [3] on a sample of 265 traffic accidents, which were analysed for possibility of obstacle avoidance, showed that $52.7 \%$ of the drivers tried to avoid crash by braking, $2.3 \%$ of the drivers tried to avoid crash only by steering to the side, while both braking and steering to avoid crash were performed by $43.4 \%$ of the drivers.

Lane change is done by using a steering mechanism, by which the vehicle is redirected most often to free the road area and it represents a very complex manoeuvre. In the reconstruction of traffic accidents, one of the basic questions about the issue of steering refers to determining the possibility of avoiding an accident on the available road distance. In other words, it is necessary to determine the distance that the vehicle travels along the main direction, i.e. X-axis, in order to achieve lateral offset along the $Y$-axis, which is perpendicular to the original direction (Figure 1).

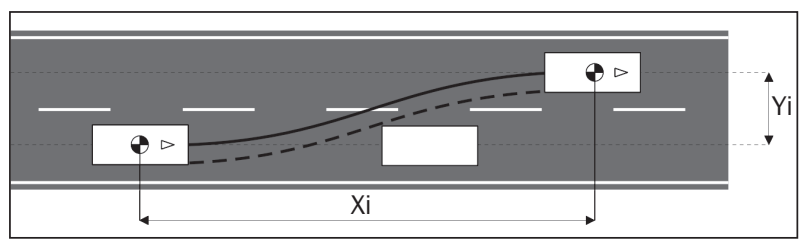

Figure 1 - Obstacle avoidance lane change manoeuvre 
Numerous mathematical models that describe vehicle lateral manoeuvre are mostly based on theory and certain simplifications, so they do not include one of the most important categories for performing this manoeuvre, which is the behaviour of drivers. In the previously mentioned studies it was shown that the drivers' response is also different in a situation when a decision needs to be made which avoiding action should be performed. Knowing that, it is quite realistic to expect that the parameters that describe movement of the vehicle during lateral manoeuvre will be somewhat different from case to case and from driver to driver. Considering this statement, a hypothesis was defined, according to which it is possible to define an empirical model for the calculation of lane change distance, based on experimental research with drivers of different age and driving experience and under conditions which can be repeatable.

\section{BACKGROUND RESEARCH}

Vehicle lane change manoeuvre has been the research subject of experts from different areas. A few decades ago, keeping linear motion was considered the most important characteristic in driving. Nowadays, lane change manoeuvre has become one of the most present ones in the procedure to determine dynamic performances of a vehicle. Experts from the area of motor vehicles researched the issue of lane change within numerous studies which tested vehicle steering characteristics in extreme conditions, with engagement of high values of lateral acceleration. Obstacle avoidance by lane change is one of the basic concepts of building autonomous intelligent vehicles. Experts from the area of traffic accident reconstruction have also been analysing the possibilities of obstacle avoidance by lane change $[4,5]$.

As a vehicle is moving in a straight line, it is not affected by lateral forces, so lateral acceleration equals zero. As the manoeuvre begins, due to centrifugal force, lateral acceleration increases up to its maximum value. Then, the intensity of lateral acceleration decreases, so that at some point it equals zero, and after that it keeps increasing, reaching a maximum value similar to the previous one, but negative. Lateral acceleration then decreases, and, after lateral stability is established, it approaches zero.

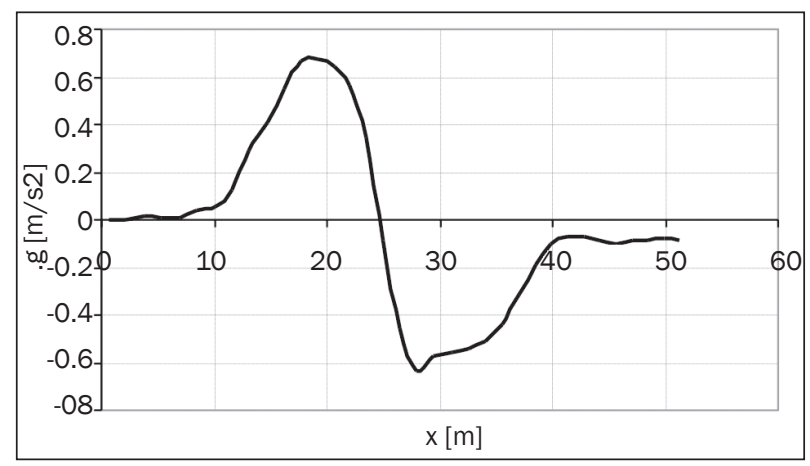

Figure 2 - Lateral acceleration of a vehicle during lane change manoeuvre
Considering the shape of vehicle lateral acceleration curve, several authors [6, 7] gave their recommendations for the use of a sinusoidal function to describe the vehicle trajectory during the manoeuvre, since this function is continuous and with continuous curvature. Zellner et al. [6] proposed the function to describe sinusoidal trajectory during the lane change process:

$$
y(x)=y_{e} \cdot\left[\frac{x}{x_{e}}-\frac{1}{2 \pi} \cdot \sin \left(\frac{2 \pi}{x_{e}} \cdot x\right)\right]
$$

where:

$x_{e}$-longitudinal lane change distance;

$y_{e}$-lateral lane change distance.

By double derivation of this expression, vehicle lateral acceleration function during the steering manoeuvre was established. Under the assumption that the manoeuvre is performed at a constant speed, the described function can be expressed by the time $(t=X / V)$, so that the value $x_{e}$ corresponds to the total lane change duration $t_{e}$. Using the fact that the vehicle lateral acceleration function reaches its maximums approximately in the first and third quarter of the lane change period, an expression was defined that says that the distance necessary to perform the manoeuvre is:

$$
x_{e}=V_{0} \cdot 2.51 \cdot \sqrt{\frac{Y_{e}}{a_{y}}}
$$

where:

$a_{y}$ - peak lateral acceleration during lane change manoeuvre.

Fett [8], Fricke [5] and Daily [4] derived a proof according to which the ideal lane change trajectory can be described by a circular arc. Fett [8] described the movement of a vehicle during lane change with two circular arcs of the same radius $R$, but with opposite orientation.

$$
\begin{array}{ll}
y(x)=R-\sqrt{R^{2}-x^{2}} & \text { for } 0 \leq x \leq \frac{x_{e}}{2} \\
& \text { for } \frac{x_{e}}{2} \leq x \leq x_{e}
\end{array}
$$

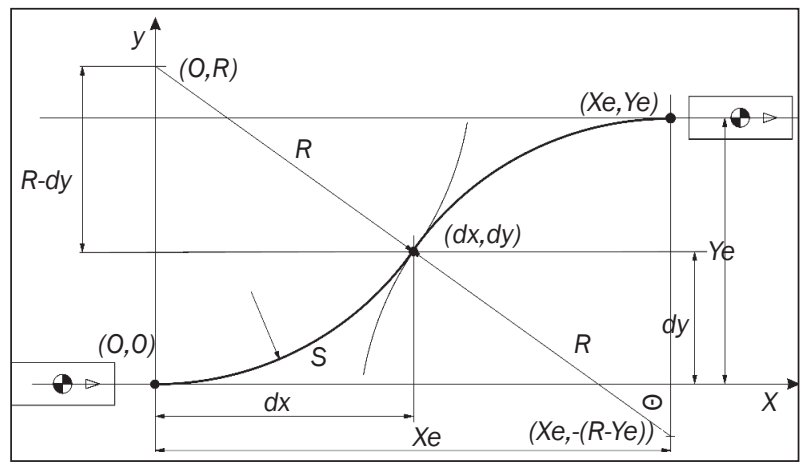

Figure 3 - Geometrical presentation of vehicle lane change on double arc trajectory 
By geometrical analysis of a trajectory described in this way, trajectory radius during the vehicle lane change manoeuvre can be expressed as:

$R=\frac{x_{e}^{2}+y_{e}^{2}}{4 y_{e}}$

Matching the values of centrifugal force and inertia during the movement on the trajectory with a radius $R$, we get the relation:

$R=\frac{V^{2}}{a_{y}}$

Based on Equation 4 and Equation 5, the vehicle lane change distance on the trajectory described by double circular arc is:

$x_{e}=2 \cdot \sqrt{\frac{V^{2} \cdot y_{e}}{a_{y}}-\left[\frac{Y_{e}}{2}\right]^{2}}$

In order to determine the minimum longitudinal lane change distance, Daily [4] matched the distance needed to perform the entry lane change manoeuvre on the path marked by an arc to the distance needed to perform the exit manoeuvre, after the lane change. Due to a different approach to the problem, vehicle lane change distance described in this way is:

$x_{e}=V \cdot 2.82 \cdot \sqrt{\frac{y_{e}}{a_{y}}}$

As a way to model the vehicle lane change manoeuvre, Chee [9] gave a mathematical model based on a cosine approximation of an arc.

$y(t)=\frac{y_{e}}{2} \cdot\left(1-\cos \left(\frac{t}{T} \cdot \pi\right)\right), 0 \leq t \leq T$

where:

$T$-time needed to perform the complete manoeuvre $\left(t_{e}\right)$.

Using double derivation of vehicle trajectory function during the lane change manoeuvre, with consideration of maximum lateral accelerations, an expression for lane change distance was determined:

$x_{e}=V \cdot 2.22 \cdot \sqrt{\frac{y_{e}}{a_{y}}}$

Nelson [10] described instantaneous lateral positon of a vehicle as a function of its longitudinal position by a $5^{\text {th }}$ degree polynomial. This function was given in the form that provides a constant curvature of lane change curve and is as follows:

$y(x)=y_{e} \cdot\left[10 \cdot\left[\frac{x}{x_{e}}\right]^{3}-15 \cdot\left[\frac{x}{x_{e}}\right]^{4}+6 \cdot\left[\frac{x}{x_{e}}\right]^{5}\right]$

Based on the established theory and certain approximations, lane change distance based on a trajectory modelled by a $5^{\text {th }}$ degree polynomial is:

$x_{e}=V \cdot 2.4 \cdot \sqrt{\frac{y_{e}}{a_{y} \max }}$

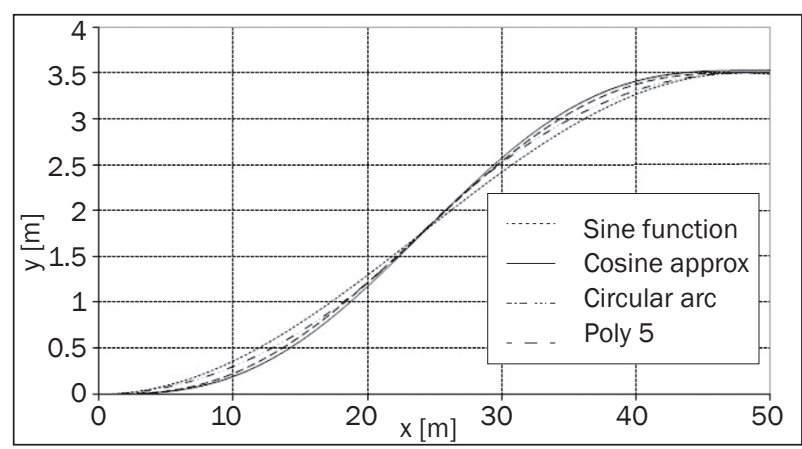

Figure 4 - Comparative view of vehicle trajectories during the lane change manoeuvre

As can be seen, forms of vehicle trajectories during lane change, as well as lane change distance, are different depending on the way of modelling and different approaches to the problem. Figure 4 shows a comparative view of vehicle trajectories modelled by a sinusoidal acceleration function, circular arc, cosine approximation of an arc and $5^{\text {th }}$ degree polynomial.

This analysis shows that, for the most of the described models, the expression for calculation of lane change distance is:

$x_{e}=V \cdot C_{x} \cdot \sqrt{\frac{y_{e}}{a_{y}}}$

where the value of coefficient $C_{x}$ is between 2.22 and 2.82 .

Based on experimental research, using the mean value of vehicle lateral acceleration during the lane change manoeuvre, Limpert [11] defined a relation for calculation of lane change distance using the model from Equation 12, where the value of coefficient $C_{x}$ is 2.6. Araszewski, et al. [12], based on a research done on a sample of 15 lane change manoeuvres, for the relation from Equation 12, determined the mean value of coefficient $C_{x}$ of 2.7, (SD 0.2).

\section{HYPOTHESIS}

The lane change distance is conditioned by the regime of the vehicle movement, that is, the intensity of lateral acceleration and the lane change width. On the other hand, the application of modern electronic devices enabled precise measuring of parameters relevant for the analyses of lane change manoeuvres, that is, speed, time, distance, lateral acceleration, the current direction and other.

In this way, with an adequate concept of experimental test track, it is possible to analyse the influence of different input velocities and the intensity of lateral acceleration to the distance necessary for obstacle avoidance by lane change manoeuvre.

\section{METHODOLOGY}

The main idea for establishing an empirical model for the calculation of vehicle obstacle avoidance lane change distance was based on Equation 12, through which the value of coefficient $C_{x}$ can be expressed as a 
function of measureable and previously defined physical values.

$$
C_{x}=x_{e} \cdot \sqrt{\frac{a_{y \max }}{V^{2} \cdot y_{e}}}
$$

In order to be able to repeat the experiment under the same conditions, the test track for vehicle lane change manoeuvre was based on the procedure described in the standard ISO 3888-2, Passenger cars - Test track for a severe lane-change manoeuvre, Part 2 Obstacle avoidance [13].

Since the research subject of this paper is lane change for obstacle avoidance, for the needs of the experimental research, the test track was modified by making the road shorter by two sections that refer to the vehicle going back to its original direction, after the lane change, so the total length of the test track was $36.5 \mathrm{~m}$, while the section width remained dependent on the vehicle width (B) and was equal to $1.1 \mathrm{~B}+025 \mathrm{~m}$ for entry and $\mathrm{B}+1 \mathrm{~m}$ for the exit gate [14].

The second modification refers to the variable vehicle lane change field width. In the test defined by standard ISO 3888-2, lane offset is constant and it is $1.0 \mathrm{~m}$. In order to test the influence of lateral lane change distance on the longitudinal lane change distance, in this test the exit gate was moved compared to the entry gate by widths of $1.0 \mathrm{~m}, 1.5 \mathrm{~m}, 2.0 \mathrm{~m}$ and $2.5 \mathrm{~m}$. The goal of the experimental research was to drive through the entry and exit gates at maximum speed, in different vehicles and to measure the values relevant for the manoeuvre (speed, lateral acceleration, time, distance). A successful manoeuvre meant the passing of a vehicle through both gates, without damaging the borders of the test track defined by cones. The modified test track for obstacle avoidance manoeuvre is shown in Figure 5.

Participants in the experimental research were drivers between 25 and 45 years of age, with 5 to 25 years of driving experience (Figure 6), who drove vehicles 3.5-4.5 $\mathrm{m}$ in length (Chevrolet Spark - $3.5 \mathrm{~m}$, Citroen Saxo - 3.7 m, Daewoo Racer - 4.2 m, Renault Megane - $4.2 \mathrm{~m}$, Fiat Stilo - $4.5 \mathrm{~m}$ ).

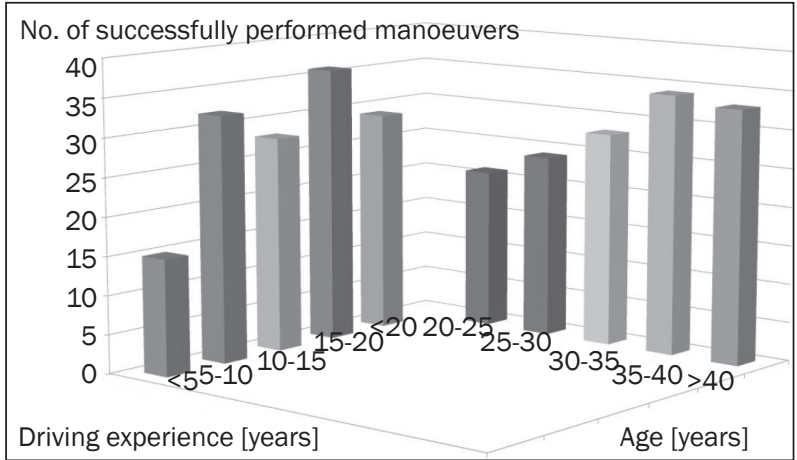

Figure 6 - Distribution of experiment participants by age and driving experience

Parameters relevant for the analysis of lane change manoeuvre were measured by GPS Data Logger Performance Box Sport and accelerometer Vericom VC3000 , at a frequency of $10 \mathrm{~Hz}$. A receiver antenna was put at the back of each car that participated in the research before the measurements were taken, in order to determine the trajectory of this specific point during the test.

In order to verify the research results, a comparative analysis of the GPS trajectory during the manoeuvre and the trajectory described by water trace method was done, based on the apparatus positioned in the middle of the back part of the vehicle. A part of the vehicle trajectory described by the water trace method during the lane change manoeuvre is presented in Figure 7.

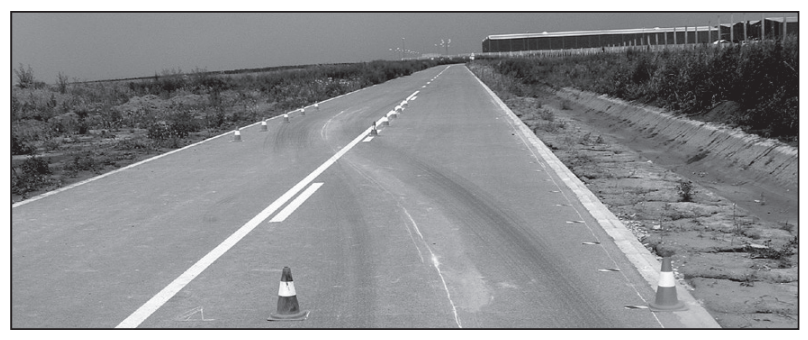

Figure 7 - Vehicle trajectory during the movement through the test track described by water trace method

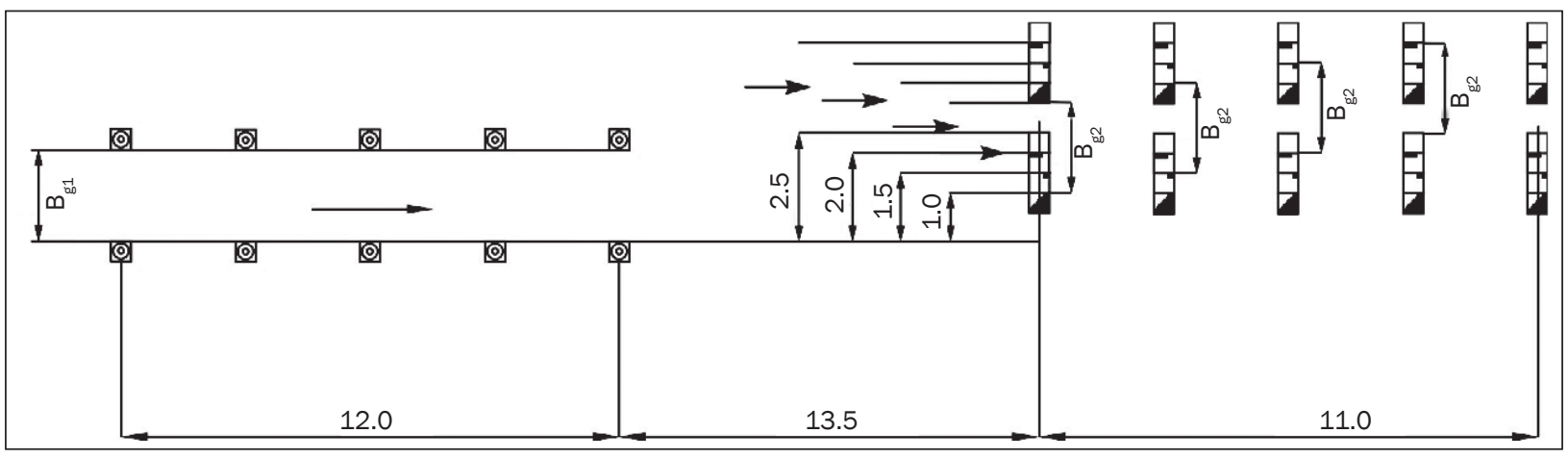

Figure 5 - Modified obstacle avoidance test track 
By comparative analysis, it was determined that vehicle trajectory during the obstacle avoidance lane change manoeuvre recorded by the GPS device does not differ from the trajectory described by the water trace method. Considering this fact, vehicle movement parameters during manoeuvre recorded by the GPS device can be considered completely relevant for determination of the longitudinal distance necessary to perform this manoeuvre. Comparative view of vehicle trajectory during lane change manoeuvre described by the GPS device and water trace method is given in Figure 8.

From the aspect of a vehicle as a technical system, the lane change manoeuvre starts at the moment when its direction of movement changes, i.e. when the vehicle centre of gravity starts swerving from its straight line trajectory, which it followed until then. At the same time, centrifugal force appears, which causes the increase in lateral acceleration intensity.

The vehicle obstacle avoidance lane change manoeuvre starts at the moment when its direction of movement starts changing, and it ends when the vehicle, after it has avoided the obstacle and changed lane at a certain width, takes a position similar to the initial one.

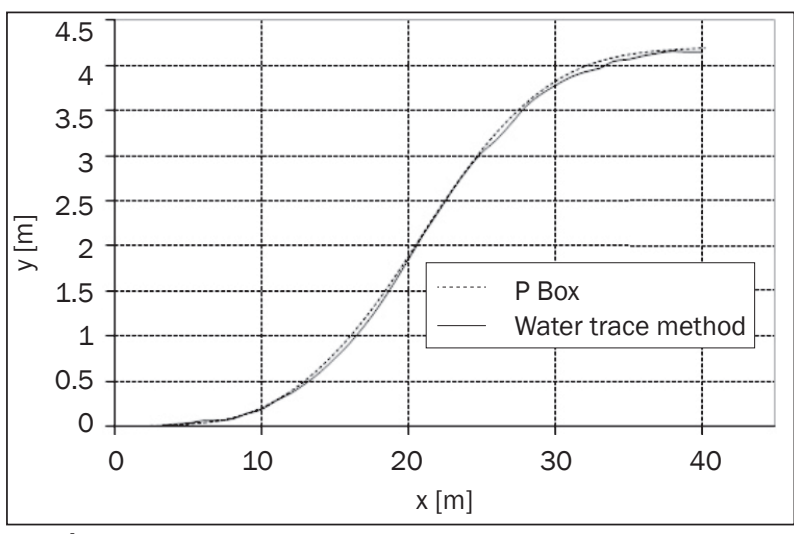

Figure 8 - Comparative view of trajectories obtained by GPS device and water trace method

Table 1 - Measured characteristic values that define movement of the vehicle through the test grounds during one of the lane change maneuvers

\begin{tabular}{|c|c|c|c|c|c|c|}
\hline Time (s) & Distance (m) & Speed $(\mathrm{km} / \mathrm{h})$ & Lateral deceleration (g) & Direction (deg) & Lateral offset (m) & Position \\
\hline 0 & 0 & 66.28 & -0.013 & 0 & 0 & a \\
\hline 0.1 & 1.83 & 66.09 & 0.035 & 0.11 & 0 & \\
\hline 0.2 & 3.67 & 65.90 & 0.045 & 0.25 & 0.01 & \\
\hline 0.3 & 5.50 & 65.86 & 0.052 & 0.41 & 0.02 & $\mathrm{~b}$ \\
\hline 0.4 & 7.32 & 65.72 & 0.126 & 0.8 & 0.05 & \\
\hline 0.5 & 9.15 & 65.69 & 0.204 & 1.43 & 0.09 & \\
\hline 0.6 & 10.97 & 65.49 & 0.398 & 2.66 & 0.17 & c \\
\hline 0.7 & 12.78 & 65.02 & 0.604 & 4.54 & 0.32 & \\
\hline 0.8 & 14.58 & 64.49 & 0.797 & 7.04 & 0.54 & $d$ \\
\hline 0.9 & 16.37 & 64.32 & 0.709 & 9.27 & 0.83 & \\
\hline 1.0 & 18.15 & 63.78 & 0.548 & 11.01 & 1.17 & \\
\hline 1.1 & 19.92 & 63.37 & 0.560 & 12.8 & 1.57 & e \\
\hline 1.2 & 21.67 & 62.81 & 0.589 & 14.7 & 2.03 & \\
\hline 1.3 & 23.41 & 62.36 & 0.249 & 15.51 & 2.51 & \\
\hline 1,4 & 25.14 & 62.26 & -0.332 & 14.43 & 2.95 & $f$ \\
\hline 1.5 & 26.87 & 62.13 & -0.660 & 12.28 & 3.33 & \\
\hline 1.6 & 28.59 & 61.88 & -0.673 & 10.08 & 3.63 & \\
\hline 1.7 & 30.30 & 61.53 & -0.684 & 7.83 & 3.87 & g \\
\hline 1.8 & 32.01 & 61.12 & -0.664 & 5.63 & 4.03 & \\
\hline 1.9 & 33.70 & 60.84 & -0.631 & 3.53 & 4.14 & \\
\hline 2.0 & 35.39 & 60.67 & -0.620 & 1.46 & 4.18 & \\
\hline 2.1 & 37.07 & 60.50 & -0.529 & 0 & 4.17 & $\mathrm{~h}$ \\
\hline 2.2 & 38.75 & 60.60 & -0.380 & -1.58 & 4.12 & \\
\hline 2.3 & 40.44 & 60.57 & -0.167 & -2.14 & 4.06 & \\
\hline 2.4 & 42.12 & 60.33 & 0.068 & -1.91 & 4.01 & \\
\hline 2.5 & 43.79 & 59.83 & 0.133 & -1.46 & 3.96 & \\
\hline
\end{tabular}




\section{RESULTS}

Analysis of vehicle lane change distance was done on a sample of 140 successfully performed manoeuvres. The measured values for one of the manoeuvres are given in Table 1. This table, as well as Figure 9, show characteristic positions of the vehicle at the entrance of the test track (a), during its movement through the entry gate $(b, c)$, at the moment when the vehicle reaches the peak lateral acceleration (d), during the movement through the transitional section (e), at the moment of entry into exit gate (f), during its movement through the exit gate $(\mathrm{g})$ and at the moment of

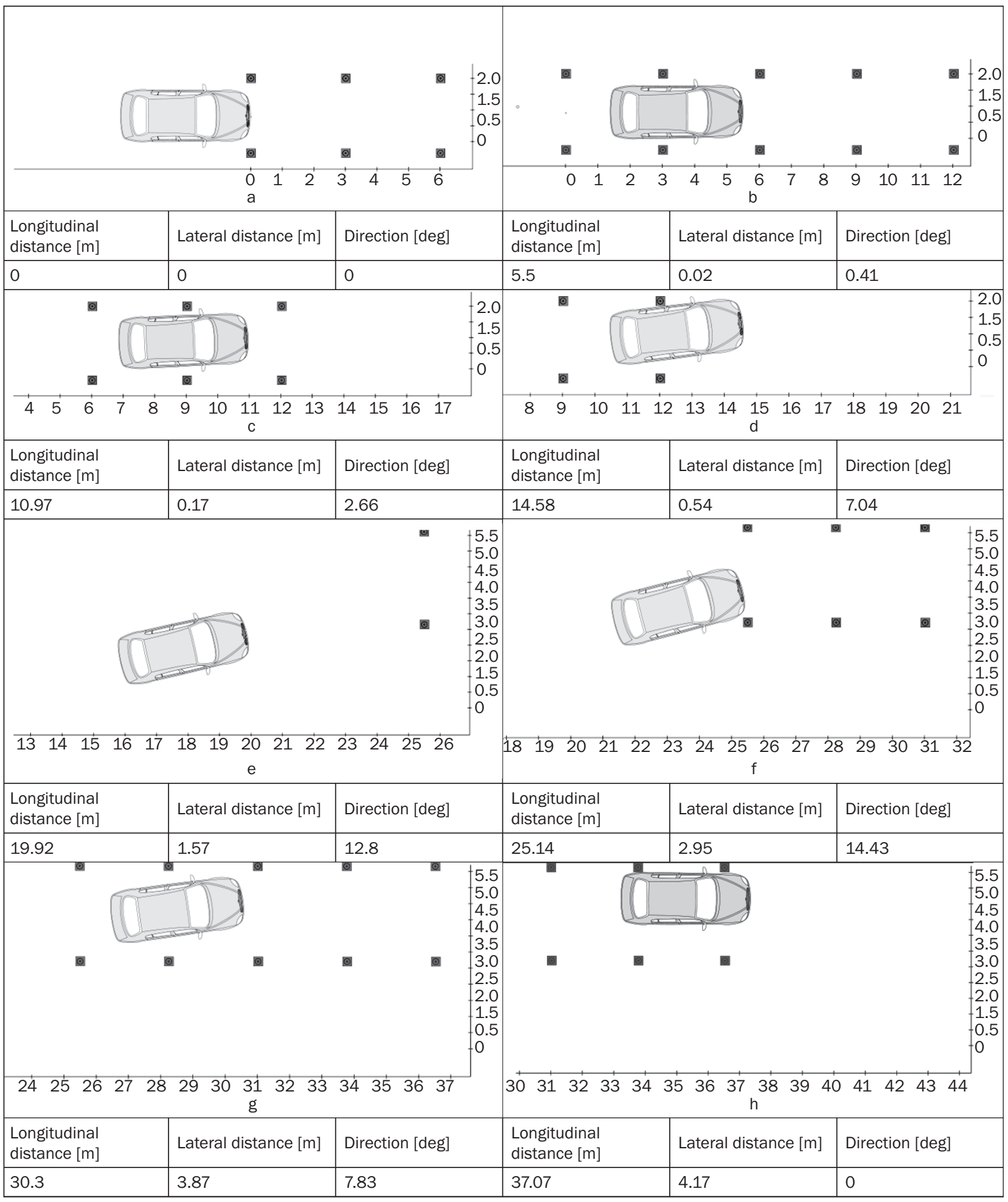

Figure 9 - Characteristic positions of one of the vehicles during its movement through the test track 


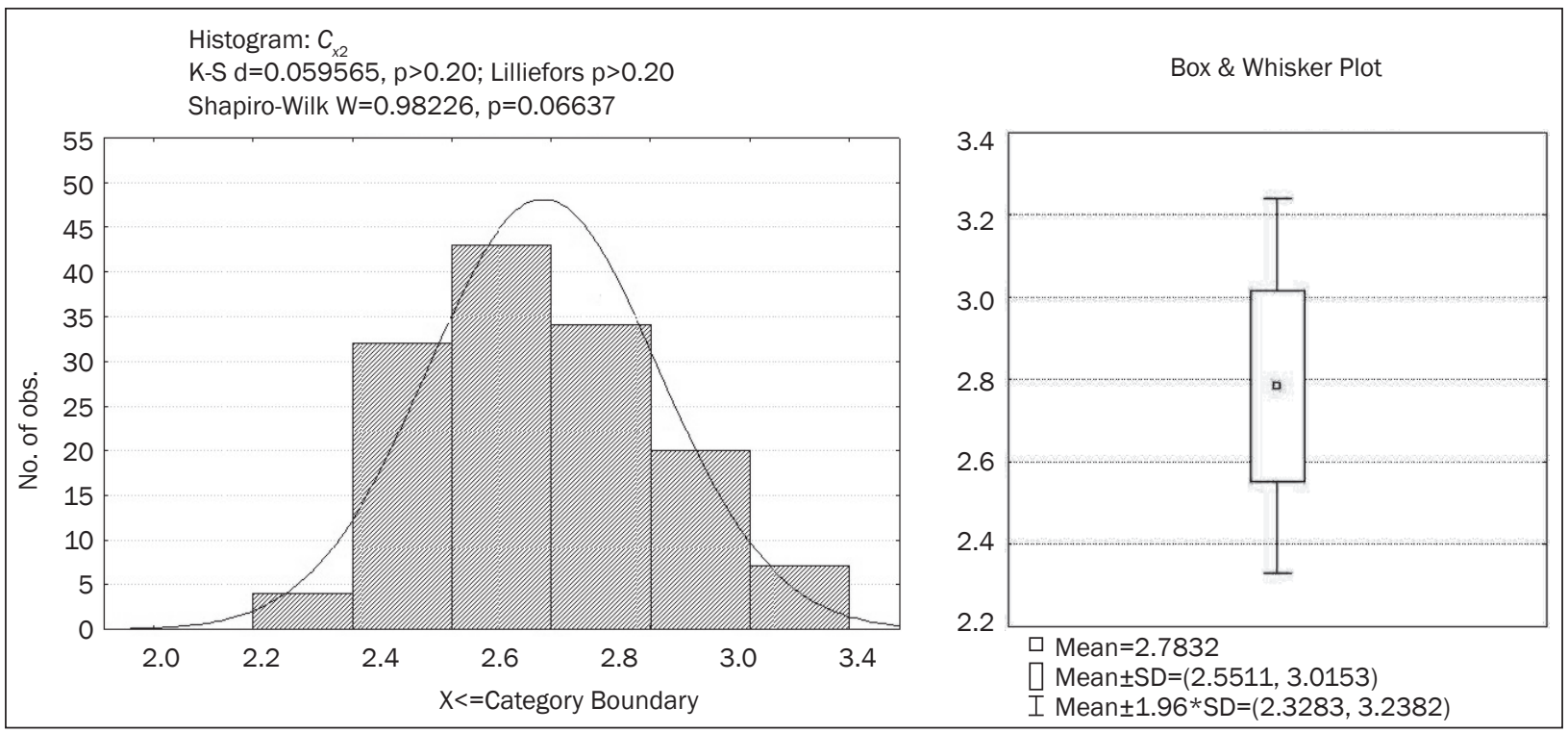

Figure 10 - Histogram and box diagram of distribution of coefficient $C_{x}$ values in the examined sample

Table 2 - Statistical indicators of analysis of coefficient $C_{x}$ values in the examined sample

\begin{tabular}{||c|c|c|c|c|c|c|c|c||}
\hline \hline Sample & Mean & Min. & Max. & SD & Skewness & St. Error Skewness & Kurtosis & St. Error Kurtosis \\
\hline \hline 140 & 2.783214 & 2.28 & 3.38 & 0.232110 & 0.232110 & 0.204847 & -0.552621 & 0.40694 \\
\hline
\end{tabular}

manoeuvre end, i.e. taking the direction parallel to the initial one (h).

Calculation of coefficient $C_{x}$ values was done based on Equation 13. Figure 10 shows histogram and box diagram of frequencies of coefficient $C_{x}$ values obtained by research, while the statistical analysis results are shown in Table 2.

Based on the results of the analysis, it can be concluded that $95 \%$ of the value of the observed sample is within the interval of 2.33 to 3.23 . According to the analysis, empirical model for calculation of the longitudinal distance necessary to perform lane change manoeuvre would have the form of:

$X_{\mathrm{e} 2}=2.78 \cdot v \cdot \sqrt{\frac{Y_{\mathrm{e} 2}}{\mu_{\mathrm{s}} \cdot g}}$

where vehicle speed is expressed in $(\mathrm{m} / \mathrm{s})$.

\section{DISCUSSION}

Depending on the research purpose and initial hypotheses, several theoretical mathematical models were developed that describe lane change manoeuvre. These models were founded on the assumptions that the manoeuvre is performed at a constant speed, as well as that each steering action is momentarily expressed through arc-shaped vehicle movement. At the same time, the reaction time needed to perform the steering manoeuvre is not taken into consideration, nor is the mechanical time of the response of the steering mechanism to the turning of the steering wheel. Apart from the mentioned simplifications, there are also differences in the approach to the mathematical modelling of the vehicle lane change process. Sledge and Marshek gave an analytical analysis of vehicle trajectories and their comparison in their paper [14].

Empirical modelling of vehicle lane change manoeuvre was based on the results of experimental research and certainly describes it in a more reliable way, compared to theoretical mathematical models. Establishing a model for obstacle avoidance lane change distance, the borderline possibilities of five different types of vehicles and several drivers that drove them were treated. The base of the model includes only the manoeuvres that were successfully performed, without damaging the test track borders outlined by cones. The research did not include the manoeuvre where the driver, apart from lane change, also reacts by braking. Such manoeuvre in itself is extremely complex, so it is very difficult to ensure the repeated experiments under similar conditions, in order to provide a sample big enough for statistical analysis. Apart from that, braking would additionally affect the uneven contact of tyres and the surface, with significant risk of destabilisation, which could even result in vehicle rollover. This manoeuvre certainly cannot be expected from an average driver, especially if we consider that the whole research was done for the needs of traffic accident reconstruction.

The analysis showed that, during the manoeuvre, test grounds exit speed was about 10\% lower than the 
entry speed, which is the result of speed decrease due to transmission resistance, rolling resistance and air resistance, which is about $0.75 \mathrm{~m} / \mathrm{s} 2$ for the length of the tested section.

Out of the total of 140 successfully performed manoeuvres, $92(65.7 \%)$ were performed in the entry speed range of $60-65 \mathrm{~km} / \mathrm{h}$, where the peak lateral acceleration value was $0.72 \mathrm{~g}$ (SD 0.028). Maximum speeds in successfully performed manoeuvres in the range of $70-75 \mathrm{~km} / \mathrm{h}$ were reached in six cases, where mean peak lateral acceleration value was $0.86 \mathrm{~g}$ (SD 0.062).

The value of coefficient $C_{x}$ in the expression for calculation of lane change distance of 2.78 (SD 0.23), determined by the experiment, is the closest in its value to the value determined by the model of the trajectory described by a circular arc (3.24.) and to the coefficient obtained from one of the experimental studies [12].

\section{CONCLUSION}

Vehicle lane change manoeuvre is a movement initiated by the driver using the steering wheel, whose consequence is lateral movement of the vehicle compared to the movement direction up to then. This manoeuvre is most often applied in usual traffic situations during overtaking or lane change. Each of these actions was previously planned and the driver initiates them after making sure they can perform them in a safe manner, with the option of aborting the action, waiting for a more favourable situation. On the other hand, in some traffic situations, the driver is forced to perform the lane change abruptly, in order to avoid an obstacle that appeared suddenly or was identified too late. In these situations, the possibilities of aborting the action that has already been started are minimal, and the obstacle avoidance depends on the subjective characteristics of the driver and abilities of the vehicle as a technical system.

Analysing the existing research of the issues dealing with lane change, it has been determined that most of the models that describe this manoeuvre were based on theory and numerous simplifications that distance them from reality to an extent. The main identified shortcomings of the existing lane change manoeuvre models are:

- uniform treatment of obstacle avoidance manoeuvre by lane change and lateral manoeuvre for lane change or overtaking;

- assumption that the whole manoeuvre, regardless of why it is being performed, is done at a constant vehicle speed;
- assumption that the steering manoeuvre is momentarily expressed through arc-shaped movement of the vehicle;

- neglecting the time of the response of the steering mechanism to the turning of steering wheels;

- disregard of subjective abilities and motivation of drivers;

- some of the models treat uniformly lateral manoeuvre for obstacle avoidance and lateral manoeuvre by obstacle width.

For the abovementioned reasons, an idea was initiated to establish an empirical model of the vehicle lateral manoeuvre, which would be based on experimental results. In order to realize this idea, it was necessary to provide an appropriate sample, and for the research results to be meaningful, the experiment had to be performed under conditions that enable it to be repeated. In that sense, the research was performed according to a modified procedure prescribed by ISO 3888-2 standard, which defines the conditions and procedure for vehicle lateral manoeuvre for obstacle avoidance. In that way, the manoeuvre mostly depended on the subjective abilities of the driver. Heterogeneous sample was provided with different makes and sizes of the vehicles (from $3.5 \mathrm{~m}$ to $4.5 \mathrm{~m}$ in length) and drivers of different age and driving experience.

Considering the established criteria for performance of the manoeuvre and the available results of the experimental research, it was concluded that the empirical model to determine the lane change distance should be based on determining the value of coefficient $C_{x}$, as a factor in manoeuvre performance. Based on the statistical analysis of the research results on a sample of 140 performed test drives, it was determined that the empirical distribution of coefficient $C_{x}$ values for vehicle lateral manoeuvre is in accordance with normal distribution. The established distribution parameters were used to define an empirical model for calculation of lane change distance, which can be applied in the procedure of traffic accidents expertise, as well as within the concept of development of autonomous intelligent vehicles.

\section{Dr ZORAN PAPIĆ ${ }^{1}$}

E-mail: njele@uns.ac.rs

Dr GORAN ZOVAK ${ }^{2}$

E-mail: goran.zovak@fpz.hr

Dr VUK BOGDANOVIĆ ${ }^{1}$

E-mail: vuk@uns.ac.rs

MSc NENAD SAULIĆ ${ }^{1}$

E-mail: nenadsaulic@gmail.com

${ }^{1}$ Univerzitet Novi Sad, Fakultet tehničkih nauka, Departman za saobraćaj

Trg Dositeja Obradovića 6, 21000 Novi Sad, Srbija

2 Sveučilište u Zagrebu, Fakultet prometnih znanosti

Vukelićeva 4, 10000 Zagreb, Hrvatska 


\section{EMPIRIJSKI PRISTUP UTVRĐIVANJU DUŽINE PUTA IZMICANJA PRILIKOM IZBEGAVANJA NALETA NA PREPREKU}

\section{REZIME}

Izbegavanje naleta na iznenadnu prepreku bočnim izmicanjem vozila predstavlja značajan i jedinstven problem za stručnjake koji se bave ekspertizama saobraćajnih nezgoda. Većina matematičkih modela za određivanje dužine puta bočnog izmicanja vozila zasnovana je na teorijskim istraživanjima i brojnim pojednostavljenjima i aproksimacijama. Kako bi se analizirao uticaj različitih vozača i tipova vozila na manevar, izvršeno je eksperimentalno istraživanje manevra bočnog izmicanja na test stazi koja omogućava ponovljivost eksperimenta pod istim uslovima. Vozači su instruisani da kroz test stazu pokušaju proći maksimalnom brzinom, bez urušavanja njenih granica definisanih saobraćajnim čunjevima. Na osnovu statističke analize uspešno realizovanih manevara, formiran je empirijski model za izračunavanje dužine puta bočnog izmicanja prilikom izbagavanja naleta na prepreku. Ovaj model se može primeniti u postupku rekonstrukcije saobraćajnih nezgoda, kao i u okviru koncepta razvoja savremenih inteligentnih vozila.

\section{KLUUČNE REČI}

izmicanje; izbegavanje naleta na prepreku; bočno ubrzanje; dužina puta; model;

\section{REFERENCES}

[1] Malaterre B, Ferrandez F, Fleury D, Lechner D. Decision Making in Emergency Situations, Ergonomics, 1988;31(4):643-655.

[2] Limpert R, Gamero FE. The Accident Avoidance Potential of the Motor Vehicle: Accident Data, Vehicle Handling and Safety Standards. Proceedings of the Third International Congress on Automotive Safety, Volume 11; Washington D.C.; 1974.

[3] Hatterick GR, Bathurst JR. Accident Avoidance Skil Training and Performance Testing (Final Report No. DOT/HS 801852). Falls Church, VA: URSIMatrix Company; 1976.
[4] Daily J. Fundamentals of Traffic Accident Reconstruction. Chapter 6: Derivation of the Lane-change Maneuver Formula. Jacksonville, FL: IPTM; 1988.

[5] Fricke LB. Traffic Accident Reconstruction. The Traffic Accident Investigation Manual, Vol. 2. Evanston, IL: Northwestern University Traffic Institute; 1990.

[6] Zellner JW, Weir DH. Development of Handling Test Procedures for Motorcycles. SAE Technical Paper 780313; 1978.

[7] Enke K. Possibilities for Improving Safety Within the Driver-Vehicle-Environment Control Loop. The 7th International Technical Conference on Experimental Safety Vehicles. Washington, DC: National Highway Traffic Safety Administration; 1979.

[8] Fett IHC. Simulation of Lane Change Maneuvers on Intersection Approaches [Master Thesis]. Austin: University of Texas; 1974.

[9] Chee W, Tomizuka M. Vehicle Lane-Change Maneuver in Automated Highway Systems. California PATH Research Report UCB-ITS-PRR-94-22. Berkeley: Institute of Transportation Studies, University of California; Oct. 1994.

[10] Nelson W. Continuous Curvature Path for Autonomous Vehicles. IEEE International Conference on Robotics and Automation; May 1989.

[11] Limpert R. Motor Vehicle Accident Reconstruction and Cause Analysis. 4th ed. Charlottesville, VA: The Michie Company; 1994.

[12] Araszewski M, Toor A. Lane Change Maneuver Modeling for Accident Reconstruction Applications. SAE Technical Paper Series 2002-01-0817. SAE 2002 World Congress; Detroit, Michigan; 2002.

[13] International Standard ISO 3888-2. Passenger cars Test track for a severe lane change manoeuvre - Part 2: Obstacle avoidance. Geneva 20, Switzerland; 2002.

[14] Papić Z. Contribution to the Research of Lane Change Manoeuvre for the Purpose of Traffic Accidents Expertise [Ph.D. thesis, in Serbian]. Novi Sad: Fakultet tehničkih nauka; 2010.

[15] Sledge N, Marshek K. Comparison of Ideal Vehicle Lane-Change Trajectories, SAE Technical Paper 971062. International Congress and Exposition; Detroit, Michigan; Feb. 1997. 